\title{
Gastroprotective Effect of Acacia aroma Gill. ex Hook. and Arn. Leaves Extracts in Gastric Ulcer Models in Rats
}

\author{
Felix Facundo Taboada', Natalia Cecilia Habib' ${ }^{1}$, Susana Beatriz Genta ${ }^{2, *}$ \\ 'Instituto de Biología, Facultad de Bioquímica, Química y Farmacia, Universidad Nacional de Tucumán and Instituto Superior de Investigaciones Biológicas (INSIBIO), \\ Consejo Nacional de Investigaciones Científicas y Técnicas (CONICET), Chacabuco 461, San Miguel de Tucumán, ARGENTINA. \\ 2Facultad de Bioquímica, Química y Farmacia, Universidad Nacional de Tucumán, ARGENTINA.
}

\begin{abstract}
Background: Peptic ulcer is a disease caused by imbalance between protective and aggressive factors in the gastric mucosa. Acacia aroma Gill. ex Hook. and Arn. (tusca) is widely used in Argentinian's folk medicine for gastrointestinal disorders. The present study was designed to evaluate the protective effect of two $A$. aroma leaf extracts, $5 \%$ infusion and $10 \%$ hydroalcoholic extract in experimental models of acute gastric ulceration in rats. Methods: The gastroprotective action of the extracts was evaluated in absolute ethanol-induced gastric lesion models in adult Westar rats through macroscopic, histological and biochemical analyses of the stomach and gastric wall. We also determined the effects on the gastric juice parameters with a pylorus ligature model in rats. Evaluation of the acute toxicity of each extract was performed in adult normal Wistar rats. All results were statistically analyzed. Results: The lowest effective dose was $150 \mathrm{mg} / \mathrm{Kg}$ for each extract. Both of them showed a high protection of the mucosa against absolute ethanol. Pre-treatments with the extracts produced a significant increase in adherent mucus. These extracts showed
\end{abstract}

a free radical scavenging capacity and they caused a significant reduction of the malondialdehyde, reduced glutathione levels, catalase and myeloperoxidase activities. The animals presented no signs of acute toxicity indicating a high safety margin for both extracts. Conclusion: This study shows for the first time the gastroprotective efficacy of $5 \%$ infusion and $10 \%$ hydroalcoholic extract of $A$. aroma leaves, highlighting their benefits as a prophylactic approach to maintain the integrity of the gastric mucosa. Key words: Acute toxicity, Antioxidant activity, Gastroprotection, Tusca, Preclinical studies.

Correspondence

Dr. Susana Beatriz Genta,

Facultad de Bioquímica, Química y Farmacia, Universidad Nacional de Tucumán, ARGENTINA.

Phone no: +54 03814107214

Email: sbgenta@fbqf.unt.edu.ar

DOI: 10.5330/ijpi.2019.4.35

\section{INTRODUCTION}

Gastric ulcer is a deep necrotic lesion involving the entire thickness of the mucosa and the muscular is mucosa and forms a cavity surround by acute or chronic inflammation., ${ }^{1,2}$ This is a pathological disorder with increasing incidence and prevalence worldwide, the lifetime risk for developing a peptic ulcer being approximately 10\%. Several aggressive factors are involved in the complex etiology of gastric ulcer, the most common ones being non-steroidal anti-inflammatory drugs and alcohol consumption, emotional distress, Helicobacter pylori infection, inflammatory mechanisms and higher free radical generation. ${ }^{3}$

Alcohol consumption has also been commonly linked to gastric mucosal lesions including gastritis and gastric ulcer. Ethanol could induce injury through multiple pathways, producing inflammatory/necrotic reactions and oxidative stress, which in turn reduces the defense barrier and damages the tissue. ${ }^{4}$

Regardless of etiology, the injured gastric mucosa has numerous repair mechanisms that contribute to the resolution of the lesions. The first line of defense is a layer of mucin-rich mucus and bicarbonate. The epithelial surface provides a defensive barrier both by producing mucus and through its tight junctions. In addition, a migration process regulated by several growth factors restores the damaged region. The intrinsic antioxidant defense, especially through Glutathione (GSH), can be effective in controlling oxidative stress, whereas the proper blood flow in the submucosal layer can supply micronutrients and oxygen and also eliminates toxic metabolic products. ${ }^{5}$
In the clinical setting, the suppression of acid secretion through $\mathrm{H} 2$ receptor antagonists, proton-pump inhibitors and anti-cholinergic drugs are the main treatment strategy in both the healing and protection of the gastric mucosa. ${ }^{6}$ However, in recent years, much attention has been focused on improving the resistance of the stomach mucosa to ulcerative agents and studying the possibility that the quality of protection against harmful substances such as drugs or alcohol may be pharmacologically modulated. ${ }^{7}$ In this context, pre-clinical studies in an ethanol-induced ulcer model are useful to define the efficacy of potential drugs with antiulcer activity. The gastric damage produced resembles acute peptic ulcers in humans and is independent of gastric acid secretion. It is a consequence of many interacting factors, each of which can be considered a potential therapeutic target, as was interpreted by Glavin and Szabo. ${ }^{8}$

In contrast, the model of pylorus-ligation induces peptic ulcers by accumulation of gastric acid in the stomach and serves to investigate the efficacy of drugs on gastric secretions. ${ }^{9}$

In the search for new therapies, plants have always been a prototypical source of chemical compounds showing activities consistent with their possible use in the treatment or prevention of gastric ulcers. ${ }^{10}$

The use of the ethno-botanical information in medicinal plant research allows the detection of potential sources of compounds with real activity. Acacia aroma Gill. ex Hook. and Arn. is an autochthonous species widely distributed in northern and central Argentina. ${ }^{11}$ This plant (common name tusca), which belongs to the Fabaceae family, is used in folk medicine as a wound healer and antiseptic and in the treatment 
of gastrointestinal disorders. ${ }^{12}$ In addition, leaf and bark infusions have anti-inflammatory uses. ${ }^{13}$ To date there are few studies that scientifically validate the plant's traditionally described therapeutic properties, although its antibacterial activity against Gram-negative and Grampositive multi-resistant micro-organisms to antibiotic have already been demonstrated. ${ }^{14}$

Despite its frequent traditional use, which would account for its safety, there is little scientific information about its toxicity. Mattana et al. ${ }^{15}$ showed that aqueous and ethanolic extracts of $A$. aroma were safe at the cell and genomic level; however, further in vivo studies are needed to confirm the absence of adverse and/or toxic reactions to ensure their safe use.

The most evident and best known secondary metabolites reported from various Acacia species widely distributed in the world are polysaccharides (gums) and several polyphenols, including condensed and hydrolysable tannins and also flavonoids. ${ }^{16}$ Although no exhaustive phytochemical studies have been performed in A. aroma leaves, the presence of the above chemical compounds could indicate potential benefits against gastric mucosal injury generated by oxidative damage. However, to the best of our knowledge, there are no pre-clinical studies that evaluate the Gastroprotective effect of this medicinal plant in the literature. Therefore, the present study was designed to evaluate the protective activity of two A. aroma leaf extracts: infusion and hydroalcoholic extract, in experimental models of acute gastric ulceration. This work could contribute to establishing the basis for the use of extracts of this plant in joint treatments with substances recognized as aggressive to the gastric mucosa such as non-steroidal anti-inflammatory drugs.

\section{MATERIALS AND METHODS}

\section{Plant Material}

Leaves of Acacia aroma Gill. ex Hook. and Arn. used in this study were collected in September 2015 from Silípica, Santiago del Estero, Argentina, located at $28^{\circ} 06^{\prime} 29^{\prime \prime} \mathrm{S}, 64^{\circ} 08^{\prime} 49^{\prime \prime} \mathrm{W}, 170$ m.a.s.l. Voucher specimens (LIL-615923) are deposited in the herbarium of "Fundación Miguel Lillo", San Miguel de Tucumán, Argentina.

The plant material (leaves) was dried under air stream in an oven at $40^{\circ} \mathrm{C}$ and ground to a powder. Two extracts, a 5\% infusion (I) and a $10 \%$ hydroalcoholic extract (HE), were obtained from the dried plant material according to Farmacopea Argentina $7^{\circ} \mathrm{Ed} .{ }^{17}$ The extracts were filtered through Whatman filter paper $\mathrm{N}^{\circ} 4$; the $\mathrm{HE}$ was concentrated under a vacuum at approximately $40^{\circ} \mathrm{C}$ and both of them were lyophilized. The dry extracts were kept at $-20^{\circ} \mathrm{C}$ until use. Before each experiment, the extracts were dissolved in distilled water (vehicle) and given to rats by oral gavage at the established dose.

\section{Quantitative phytochemical analysis}

The total phenolic content in both extracts was determined by the FolinCiocalteu method with slight modifications. Briefly, $0.05 \mathrm{ml}$ of a solution $(1 \mathrm{mg} / \mathrm{ml}$ ) of each extract was mixed with $0.2 \mathrm{ml} 50 \%$ (v/v) Folin-Ciocalteu reagent (Sigma- Aldrich, Co. St. Louis, MO, USA) and $0.8 \mathrm{ml}$ of $14.9 \%$ sodium carbonate solution. In order to complete a final volume of $2 \mathrm{ml}$, ethanol (for organic extracts) or water (for aqueous extracts) was added. After $20 \mathrm{~min}$, the samples were read at $765 \mathrm{~nm}$ in a spectrophotometer. Gallic acid was used as a standard. The result was expressed as mg Gallic Acid Equivalents (GAE)/g dry extract.

Flavonoid content determination in both extracts was based on the formation of a flavonoid-aluminum complex as was described by Chang et al. ${ }^{18}$ Quercetin was used as a standard. The amount of flavonoids was expressed as mg quercetin equivalents/g dry extract.
The method used for tannins determination is based its property to precipitate proteins. At first the total phenolic compounds from each extract was determined with the Folin-Ciocalteu procedure described above. In order to remove tannins, BSA solution ( $0.2 \mathrm{M}$ acetate buffer, $\mathrm{pH} 5,0.17$ $\mathrm{M}$ sodium chloride and $1 \mathrm{mg}$ fraction V BSA- Sigma- Aldrich, USA) was added to the extract (1:1). After $15 \mathrm{~min}$ at room temperature, the mixture was centrifuged at $5000 \mathrm{~g}$ and an aliquot $(50 \mu \mathrm{l})$ of the supernatant was used to determine total phenolic compounds using the FolinCiocalteu method. The amount of total tannins was obtained from the difference between the amount of phenolic compounds before and after the precipitation. Total tannin content was expressed as mg GAE/g dry extract. ${ }^{19}$ All the determinations were carried out in triplicate.

\section{Free radical scavenging activity: In vitro assay}

The free radical scavenging capacity of the $5 \%$ I and $10 \%$ HE was evaluated by the decrease in 2,2-diphenyl-1- picrylhydrazyl (DPPH) absorbance accordingly to Blois. ${ }^{20}$

$\mathrm{EC}_{50}$ values were calculated by nonlinear regression analysis of the plotted DPPH depuration \% vs. sample concentration using SPSS $^{\curvearrowleft}$ statistic software. All assays were performed in triplicate.

\section{Animals}

Adult male Wistar rats aged 8 to 12 weeks (weight $200 \pm 20 \mathrm{~g}$ ) were selected for all the experiments. The animals were obtained from the colony bred at the INSIBIO (CONICET-UNT), Tucumán, Argentina and were acclimated for 7 days before the start of the experimental procedures.

The animals were housed in cages and the photoperiod (07:00 to 19:00 h), air exchange, temperature $\left(22 \pm 2^{\circ} \mathrm{C}\right)$ and relative humidity $(60-70 \%)$ of the room were controlled. Rats were given free access to a powdered certified rodent diet obtained from a commercial source (Standard Food-Asociacion de Cooperativas Argentinas-S.E.N.A.S.A. No. 2706). Water was also available ad libitum. There were no known contaminants in the food or water that could interfere with the results of the study.

All animal handling and procedures complied with the current laws of Argentina (Ethical Framework of Reference for Biomedical Research in laboratory animals, Resol. D N 1047 annex II, 2005). The current protocol was approved by the Institutional Committee of Animal Care and Use of the Facultad de Bioquímica, Universidad Nacional de Tucumán $\left(\mathrm{N}^{\circ} 0015-2017\right)$. Every effort was made to reduce the number and suffering of experimental animals.

\section{Evaluation of the gastroprotective effect}

Gastroprotective effect of Acacia aroma was studied using ethanol-induced gastric ulcer model. The rats were placed in individual cages with raised floors and fasted for $18 \mathrm{~h}$ with free access to $5 \%$ sucrose solution instead of water in order to avoid coprophagy. The animals were randomly assigned to eight groups $(n=6)$. Six groups were treated with a specific dose each one 75, 150 and $300 \mathrm{mg} / \mathrm{kg}$ body weight (b.w.) of $5 \%$ I or $10 \%$ HE. The untreated ulcer group received vehicle (distilled water), whereas the standard drug sucralfate $(100 \mathrm{mg} / \mathrm{kg} \mathrm{b.w.)} \mathrm{was} \mathrm{orally}$ administered to rats in the positive control group. In addition, the untreated normal group received only the same volume of distilled water instead of ethanol. After $60 \mathrm{~min}$, all groups were orally given absolute ethanol $(6 \mathrm{ml} / \mathrm{kg}$ b.w. $)$ to induce gastric ulcers. Animals were euthanized $1 \mathrm{~h}$ after ethanol administration with an intraperitoneal (i.p.) overdose of ketamine/xylazine (150:5 mg/kg b.w.).Their stomachs were immediately dissected, opened and rinsed with cold PBS.

The degree of gastric mucosal damage to establish the minimum protective dose of $5 \%$ I and $10 \%$ HE was evaluated by gross pathology, counting the number of ulcers per stomach. The ulcer area $\left(\mathrm{mm}^{2}\right)$ was measured using Image J 1.48d software (National Institutes of Health, USA) and 
expressed as a percentage (\%) of total area (ulcer percentage). The severity of gastric lesion was calculated according to a $0-3$ scoring system: 0 : Normal mucosa, 0.5: red mucosa, 1: spot ulcer, 1.5: hemorrhagic lines, 2: 3 or more confluent hemorrhagic lines, 3: 5 or more ulcers). The protection percentage (\%) of each assayed material was calculated using the following equation:

Protection $\%=\left[\left(\right.\right.$ ulcer $\%_{\text {ethanol control }}-$ ulcer $\left.\%_{\text {treated group }}\right) /$ ulcer $\left.\left.\%_{\text {ethanol control }}\right)\right]$ X 100. The statistical comparison of the dose-response curve provided the lowest effective dose, which was used for the next analyses.

\section{Microscopic examination of gastric damage}

Gastric tissue samples from each experimental group were fixed in $4 \%$ phosphate-buffered formaldehyde for $24 \mathrm{hr}$. Then, the samples were washed, dehydrated with alcohol, cleared in xylene and embedded in paraffin in hot air oven $\left(56^{\circ} \mathrm{C}\right)$. The paraffin blocks were cut into $5 \mu \mathrm{m}$ thick sections with a microtome (Levitz 1401, Germany).

The tissue sections obtained were deparaffinized and stained with hematoxylin and eosin, Alcan blue or Periodic Acid-Schiff (PAS) dyes for histopathological examination through the light photomicroscope (NIKON, Japan). In order to avoid bias, a qualified observer unaware of the identity of the specimens performed all histopathological procedures.

\section{Determination of the adherent gastric mucus}

The mucus content attached to the gastric wall was determined according to the method previously described by Corne et al. ${ }^{21}$ with modifications. Briefly, stomachs from each experimental group were weighed, quickly transferred to $1 \%(\mathrm{p} / \mathrm{v})$ Alcian blue solution prepared with 0.16 $\mathrm{M}$ sucrose in $0.05 \mathrm{M}$ sodium acetate, $\mathrm{pH} 5$ and incubated for $2 \mathrm{~h}$ at room temperature. Then, the organs were carefully rinsed with the above sucrose solution. The dye attached to the gastric wall was extracted with a $3 \%(\mathrm{p} / \mathrm{v})$ sodium dodecyl sulfate solution $(10 \mathrm{ml} / \mathrm{stomach})$. The resulting colored solution was centrifuged at $5000 \mathrm{rpm}(8000 \mathrm{~g})$ for $5 \mathrm{~min}$ and the absorbance of the supernatant was measured at $605 \mathrm{~nm}$. The Alcian blue $(\mu \mathrm{g})$ extracted per gram of wet organ was then calculated using a calibration curve of Alcian blue (6.26-100.00 $\mu \mathrm{g})$.

\section{Biochemical estimations of oxidative stress and inflammatory parameters}

\section{Preparation of gastric mucosa homogenates}

To obtain $10 \%(\mathrm{p} / \mathrm{v})$ aqueous homogenates, the gastric mucosa of each experimental group were scraped off, weighed and homogenized at $4^{\circ} \mathrm{C}$ in $200 \mathrm{mM}$ sodium phosphate buffer, $\mathrm{pH} 7.4$, containing 1mM EDTA and the following protease inhibitors $2 \mathrm{mM}$ phenylmethylsulfonyl fluoride, $0.5 \mu \mathrm{g} / \mathrm{ml}$ leupeptin, $5 \mu \mathrm{g} / \mathrm{ml}$ pepstatin and $5 \mu \mathrm{g} / \mathrm{ml}$ aprotinin (Sigma, USA).

After homogenization, one fraction was centrifuged at $9000 \mathrm{~g}$ for $15 \mathrm{~min}$ at $4^{\circ} \mathrm{C}$ and the resultant pellet was used to determine myeloperoxidase (MPO) activity, while another homogenate fraction was centrifuged at $18000 \mathrm{~g}$ at $4^{\circ} \mathrm{C}$ for $15 \mathrm{~min}$. The resulting supernatant was used to evaluate malondialdehyde (MDA) levels and catalase (CAT) activity. Protein estimation was carried out by the method of Lowry et al. ${ }^{22}$ using BSA as a standard.

\section{Determination of GSH levels}

GSH in stomach homogenate was measured as described by Ellman ${ }^{23}$ using the 5,5-dithiobis-(2-nitrobenzoic acid) (Sigma, USA) reagent. GSH levels were calculated using a calibration curve performed with the GSH (Sigma, USA) standard and expressed as $\mu \mathrm{g}$ GSH/mg protein.

\section{Determination of lipid peroxides level (MDA)}

Lipid peroxidation was assessed by determining the levels of MDA in supernatants of mucosa homogenate according to the spectrophotometric method of Buege and Aust. ${ }^{24}$ The MDA concentration of the sample was calculated with an extinction coefficient of $1.56 \times 10^{5} \mathrm{M}^{-1} \mathrm{~cm}^{-1}$. The results were expressed as $\mathrm{n}$ moles of MDA formed/mg protein.

\section{Determination of CAT activity}

CAT activity was measured according to the modified method of Aebi. ${ }^{25}$ Briefly, $500 \mu \mathrm{l}$ of supernatants of mucosa homogenate (containing approximately $1.5 \mathrm{mg}$ of protein) was added to $250 \mu \mathrm{l}$ of $0.1 \mathrm{M}$ phosphate buffer, $\mathrm{pH} 7$, containing $100 \mathrm{mM} \mathrm{H}_{2} \mathrm{O}_{2}$. The rate of $\mathrm{H}_{2} \mathrm{O}_{2}$ decomposition was followed spectrophotometrically at $240 \mathrm{~nm}$ for $1 \mathrm{~min}$. Enzyme activity was expressed as international Units $(\mathrm{U}) / \mathrm{mg}$ protein and was calculated using a molar extinction coefficient of $0.043 \mathrm{M}^{-1} \cdot \mathrm{cm}^{-1}$. One units of CAT was defined as nmoles $\mathrm{H}_{2} \mathrm{O}_{2}$ destroyed/min at $25^{\circ} \mathrm{C}$.

\section{Determination of MPO activity}

Myeloperoxidase activity was measured to assess neutrophil infiltration as described by Bradley et al. ${ }^{26}$ with modifications. The pellet obtained as previously described above was resuspended in $50 \mathrm{mM}$ phosphate buffer, $\mathrm{pH} 6$, containing $0.5 \%$ hexadecyltrimethylammonium bromide (Biopack, Argentina) and sonicated for $1 \mathrm{~min}$ in an ice bath. The samples were centrifuged at $600 \mathrm{~g}$ for $20 \mathrm{~min}$ at $4^{\circ} \mathrm{C}$ and the supernatants were diluted 1:30 with $50 \mathrm{mM}$ phosphate buffer, $\mathrm{pH} 6$, containing $0.167 \mathrm{mg} /$ $\mathrm{ml} \mathrm{O}$-dianisidine dihydrochloride (Sigma, USA) and $0.0005 \% \mathrm{H}_{2} \mathrm{O}_{2}$. The change in absorbance at $460 \mathrm{~nm}\left(25^{\circ} \mathrm{C}\right)$ was measured at 1 min intervals for $3 \mathrm{~min}$. One unit of MPO was defined as the $\mu \mathrm{g}$ of enzyme that degraded one micromole of peroxide per min at $25^{\circ} \mathrm{C}$. Enzymatic activity was expressed as $\mathrm{U} / \mathrm{mg}$ protein.

\section{Model of gastric ulcer induced by pylorus ligation}

This model was carried out to evaluate the effects of 5\% I and 10\% HE on gastric juice parameters. After $18 \mathrm{hr}$ fasting, male Wistar rats were divided into four groups $(n=6)$. The untreated group received vehicle (distilled water), whereas the positive control group was intraperitoneally administered the standard drug Omeprazole sodium (20 mg/kg b.w.). The treated groups orally received $5 \%$ I (150 mg/kg b.w.) or $10 \% \mathrm{HE}$ $(150 \mathrm{mg} / \mathrm{kg}$ b.w.). Sixty min after each treatment the rats were anesthetized with ketamine/xylazine $(75 / 5 \mathrm{mg} / \mathrm{kg}$ b.w., i.p.) and the abdomen was opened, the stomach was exposed and the pyloric sphincter was ligated without causing any damage to the blood supply. All the animals were euthanized $4 \mathrm{hr}$ later with an overdose of ketamine/xylazine (150:5 $\mathrm{mg} / \mathrm{kg}$ b.w., i.p.). The stomach was removed and the gastric content was collected and their volume and its $\mathrm{pH}$ were determined. It was immediately centrifuged at $2000 \mathrm{~g}$ for $10 \mathrm{~min}$. The supernatant was removed and titrated with $0.01 \mathrm{~N} \mathrm{NaOH}$ using methyl orange as an indicator. The free acid concentration was expressed in $\mathrm{mEq} / \mathrm{L} / 100 \mathrm{~g}$ b.w. The supernatant was also used for the determination of pepsin activity according to Anson. ${ }^{27}$

\section{Acute toxicity studies}

Acute oral toxicity of 5\% I and 10\% HE was studied with a single dose experiment. Healthy adult Westar rats were randomly divided into groups of six animals. Each group included three males and three females with a weight of $200 \pm 20 \mathrm{~g}$ that were orally given a single dose of $5 \% \mathrm{I}$ and $10 \% \mathrm{HE}$. The doses tested were 3.75, 7.50 and $15.00 \mathrm{~g}$ dry extract/kg b.w., representing 25, 50 and 100 times the effective Gastroprotective dose.

The control group received only the vehicle (distilled water). Rats were observed continuously for $1 \mathrm{hr}$ after treatment to evaluate their behavior, neurologic and autonomic activity and toxic effects. Then, the controls 
were carried out at 3 and $6 \mathrm{hr}$ post-dose on day 0 and twice daily (morning and afternoon) thereafter for 14 days. Food consumption, faces and urine were also examined twice daily (morning and afternoon) during the 14 days after the single dose administration of the dry extract.

\section{Statistical analysis}

All the data were expressed as mean \pm SD and evaluated by one-way analysis of variance (ANOVA) followed by unpaired Student's $t$-test using the Statistical Package for the Social Sciences version 12.0 (SPSS) program (SPSS Inc., Chicago, IL). Values of $p<0.05$ were considered as statistically significant.

\section{RESULTS}

\section{Phytochemical evaluation of 5\% infusion and 10\% hydroalcoholic extract of tusca leaves}

The yield of the $5 \%$ I was found to be $8.4 \%$ of powdered extract (w/w of plant material), whereas the $10 \%$ HE yield $14.9 \%$ of powdered extract (w/w of plant material).

The total phenolic compounds and tannin quantified in 5\% I were found to be $94.61 \pm 0.32$ and $24.50 \mathrm{mg}$ gallic acid equivalent/ $\mathrm{g}$ of dry extract, respectively. The total content of flavonoids was $82.08 \mathrm{mg} / \mathrm{g}$ (quercetin equivalent per gram of dry extract). 10\% HE showed an important content of total phenolic compounds $(72.60 \pm 0.74 \mathrm{mg}$ gallic acid equivalent/g) but especially of flavonoids (104.58 $\pm 1.06 \mathrm{mg}$ quercetin equivalent/g) and tannins $(40.62 \pm 2.03 \mathrm{mg}$ gallic acid equivalent/g dry extract) compared with the infusion.

In view of these results, we have demonstrated the in vitro DPPH radical scavenging activity of both the $5 \%$ I and the $10 \% \mathrm{HE}$. Indeed, the sample concentration of the infusion as well as the ethanol extract necessary to decrease the initial DPPH concentration by $50 \%$ ( $\mathrm{EC}_{50}$ values) were $47.5 \pm 2.4$ and $39.3 \pm 2.0 \mathrm{ug} / \mathrm{ml}$, respectively. Unsurprisingly, quercetin, the positive control for this assay, showed an $\mathrm{EC}_{50}$ of $1.7 \pm 0.1 \mathrm{ug} / \mathrm{ml}$, confirming its well-known ability for radical scavenging, whereas the $\mathrm{EC}_{50}$ values for the infusion or the ethanolic extract were significantly higher compared with quercetin $(p<0.05)$.

\section{Acute toxicity of $A$. aroma leaf extracts}

Acute oral toxicity of 5\% I and 10\% HE was evaluated in normal healthy rats. No deaths or acute toxic effects (changes in behavior or posture, presence of convulsions or occurrence of secretions) were reported within 14 days. All treatments were well tolerated and did not produce adverse nutritional effects.

No gastrointestinal symptoms such as diarrhea or constipation were observed at the doses assayed. Volume, $\mathrm{pH}$ and urine specific gravity were within normal ranges. No nitrites, protein or blood were detected in the urine samples of the animal groups treated with different doses of each extract throughout the 14 days of control. No obvious treatment-related alterations were seen in the stomach, liver or kidney weights when these were expressed in relation to body weight. (Data not shown).

In this experiment no evidence of acute toxicity was found at any dose level up to the highest doses tested ( $15 \mathrm{~g}$ dry extract/kg b.w., 100 times the effective dose). This does represent the non-observed-adverse-effect level (NOAEL), indicating that the safety margin of both extracts is high.

\section{Evaluation of the in vivo effects of 5\% infusion and 10\%} hydroalcoholic extract of $A$. aroma leaves on ethanolinduced gastric ulcer

\section{Determination of lowest effective dose}

As shown in Table 1, under our experimental conditions, effective gastric protection was achieved with pretreatment at a minimum dose of 150 $\mathrm{mg} / \mathrm{kg}$ b.w. of both $5 \%$ I and $10 \%$ HE. The ulcer percentage was significantly lower ( $1.41 \pm 0.11$ and $2.16 \pm 0.07 \%$, respectively) compared to the untreated group $(p<0.05)$, suggesting an interesting protection against the harmful agent. Taking into account the results presented in this section, the subsequent experiments were performed using only the lowest effective dose (150 mg dry extract / kg b.w.).

Table 1: Effect of $A$. aroma leaves extracts on the stomach in an ethanol induced ulcer model.

\begin{tabular}{|c|c|c|c|c|}
\hline Treatments & $\begin{array}{c}\text { Number of ulcers/ } \\
\text { stomach }\end{array}$ & $\begin{array}{l}\text { Severity of } \\
\text { gastric lesion }\end{array}$ & $\begin{array}{c}\text { Ulcer } \\
\text { Percentage (\%) }\end{array}$ & Protection (\%) \\
\hline Vehicle & 0.00 & 0.00 & 0.00 & - \\
\hline Ethanol $100^{\circ}$ & $5.33 \pm 0.27$ & $2.00 \pm 0.10$ & $7.91 \pm 0.40$ & 0.00 \\
\hline $\begin{array}{l}\text { Sucralfate } \\
(100 \mathrm{mg} / \mathrm{kg})\end{array}$ & $0.33 \pm 0.02^{\mathrm{a}}$ & $0.67 \pm 0.03^{\mathrm{a}}$ & $0.38 \pm 0.02^{\mathrm{a}}$ & $95.14 \pm 4.76$ \\
\hline $\begin{array}{l}\text { Tusca } 5 \% \text { I } \\
(75 \mathrm{mg} / \mathrm{kg})\end{array}$ & $4.98 \pm 0.09^{b}$ & $2.00 \pm 0.08^{b}$ & $6.55 \pm 0.98^{\mathrm{b}}$ & $17.2 \pm 0.86^{\mathrm{a}, \mathrm{b}}$ \\
\hline $\begin{array}{c}\text { Tusca } 5 \% \text { I } \\
(150 \mathrm{mg} / \mathrm{kg})\end{array}$ & $1.33 \pm 0.07^{\mathrm{a}, \mathrm{b}}$ & $1.00 \pm 0.05^{\mathrm{a}, \mathrm{b}}$ & $1.41 \pm 0.11^{\mathrm{a}, \mathrm{b}}$ & $82.20 \pm 4.11^{\mathrm{a}, \mathrm{b}}$ \\
\hline $\begin{array}{l}\text { Tusca } 5 \% \text { I } \\
(300 \mathrm{mg} / \mathrm{kg})\end{array}$ & $0.54 \pm 0.03^{\mathrm{a}, \mathrm{b}}$ & $0.98 \pm 0.04^{\mathrm{a}, \mathrm{b}}$ & $0.67 \pm 0.07^{\mathrm{a}, \mathrm{b}}$ & $91.5 \pm 4.58^{\mathrm{a}}$ \\
\hline $\begin{array}{c}\text { Tusca 10\% HE } \\
(75 \mathrm{mg} / \mathrm{kg})\end{array}$ & $5.01 \pm 0.09^{\mathrm{b}}$ & $2.00 \pm 0.10^{\mathrm{b}}$ & $7.20 \pm 0.10^{\mathrm{a}, \mathrm{b}}$ & $9.00 \pm 1.40^{\mathrm{a}, \mathrm{b}}$ \\
\hline $\begin{array}{c}\text { Tusca } 10 \% \text { HE } \\
(150 \mathrm{mg} / \mathrm{kg})\end{array}$ & $1.67 \pm 0.08^{\mathrm{a}, \mathrm{b}}$ & $1.00 \pm 0.05^{\mathrm{a}, \mathrm{b}}$ & $2.16 \pm 0.07^{\mathrm{a}, \mathrm{b}}$ & $72.65 \pm 3.63^{\mathrm{a}, \mathrm{b}}$ \\
\hline $\begin{array}{c}\text { Tusca } 10 \% \mathrm{HE} \\
(300 \mathrm{mg} / \mathrm{kg})\end{array}$ & $1.49 \pm 0.10^{\mathrm{a}, \mathrm{b}}$ & $1.00 \pm 0.10^{\mathrm{a}, \mathrm{b}}$ & $2.00 \pm 0.13^{\mathrm{a}, \mathrm{b}}$ & $74.7 \pm 1.70^{\mathrm{a}, \mathrm{b}}$ \\
\hline
\end{tabular}

Data are presented as the means \pm SD for $n=6$ rats per group. ${ }^{a} p<0.05$ vs. untreated ulcer group, ${ }^{b} p<0.05$ vs. sucralfate treated group. I: infusion, HE: hydroalcoholic extract. 


\section{Macroscopic analysis}

In order to determine the gastroprotective efficacy of the evaluated treatments, gross signs of damage were examined first. Oral administration of ethanol caused severe hemorrhagic gastritis with high severity scores [Table 1]. As shown in Figure 1, ulcerative lesions cover a large area, revealing extensive damage to the gastric mucosa. Interestingly, oral pretreatment with $10 \% \mathrm{HE}$ was able to reduce the extent of the ulcerated area, showing a significantly lower ulcer percentage compared with the untreated ulcer group. This is reflected in an important protection percentage of gastric lesions $(72.65 \pm 3.63 \%)$.

Similarly, oral pretreatment with $5 \%$ I significantly decreased the extension of ulcerated tissue, showing lower ulcer percentage and a high protection percentage of gastric lesion $(82.20 \pm 4.11 \%)$ in a significantly higher range than with the ethanolic leaf extract $(p<0.05)$. Although the extracts of tusca leaves were able to protect the gastric mucosa against the harmful agent $(p<0.05)$, this effect was lower than that of sucralfate at a dose of $100 \mathrm{mg} / \mathrm{kg}$.

As shown in Figure 1 and e only few fields of hyperemia were observed, with a similar aspect to the positive control group treated with sucralfate [Figure 1].

A- E: Macroscopic analysis. (A): Normal control rats. (B): Untreated ulcer rats (only ethanol administration). (C): Sucralfate $(100 \mathrm{mg} / \mathrm{kg}$ ) pretreated rats. (D): $5 \%$ I pretreated rats. (E): $10 \%$ HE pretreated rats.

A1- E1: Histological analysis. (A1): Stomach of normal rat showing normal histological structure of the mucosa and submucosa layers. (B1): Stomach of ethanol treated rat showing focal ulceration with surface mucosa loss (sl), hemorrhagic focus (hf), leukocyte infiltration (li) and submucosal edema (ed). (C1): Stomach of sucralfate $(100 \mathrm{mg} / \mathrm{kg})$ pretreated rats showing intact histological structure of the mucosa. (D1): $5 \% \mathrm{I}(150 \mathrm{mg} / \mathrm{kg})$ pretreated rats showing intact histological structure of the mucosa with scarce submucosal edema. (E1): 10\% HE (150 mg/kg) pretreated rats showing only surface mucosa scarcely attacked.

Scale bars $=25 \mu \mathrm{m}$. Hematoxylin and Eosin staining. I: infusion of $A$. aroma leaves, HE: hydroalcoholic extract of $A$. aroma leaves. Full page width.

\section{Microscopic analysis}

Sections from gastric wall samples of the different animal groups were stained with hematoxylin/eosin, Periodic Acid-Schiff (PAS) and Alcian blue dye. Normal control rats receiving the vehicle showed normal mucosal architecture with intact epithelial surface and submucosa layers [Figure 1]. In contrast, the administration of ethanol caused a severe gastric injury with surface epithelial cell destruction, loss of the surface mucosa layer and hemorrhagic points. The mucosa and sub-mucosa layers showed also diffuse leukocyte infiltration and extensive edema in the second layer [Figure 1]. Interestingly, treatment of the animals with the infusion or the hydroalcoholic extract of tusca leaves contributed to preserve the normal histology of the whole gastric wall, showing a scarcely attacked mucosa, scant inflammatory cell invasion and scarce submucosal edema [Figure 1]. These effects were very similar to those of sucralfate [Figure 1] representing a significant protective action.

All the above pretreatments resulted in a significant staining intensity with PAS dye for mucin-like glycoproteins [Figure 2], particularly of neutral mucins, which are secreted by superficial cells of the gastric epithelium to form the protective mucus layer.

In addition, sections from gastric wall stained with Alcian blue dye showed a conserved mucus layer and mucus in the gastric pit of groups pretreated with sucralfate and 5\% I [Figure 2] in a similar way to the normal control group. In the $10 \% \mathrm{HE}$ pretreated group a layer of mucus was detected, although slightly lesser than in the group treated with infusion and mainly distributed in the gastric pit [Figure 2].

A- E: PAS dye. (A): Normal control group: surface mucous cells were strongly stained with PAS. (B): Untreated ulcer group: The PAS reaction was reduced in surface cells. (C): Positive control group treated with sucralfate (100 mg/kg): the PAS reaction remained in surface cells. (D): Treated group with 5\% I (150 mg/kg) and (E): Treated group with $10 \%$ HE (150 mg/kg). Arrows mark positive mucus stain with PAS.

A1- E1: Alcian blue dye. (A1): Normal control group: the mucus was strongly stained in a mucus layer and in the gastric pit. (B1): Untreated ulcer group: the Alcian blue stain appeared reduced in surface cells. (C1): Positive control group (sucralfate, $100 \mathrm{mg} / \mathrm{kg}$ ) the mucus remained on the surface of cells and in pits. (D1): Treated group with tusca leaves 5\% I (150 mg/kg) and (E1): Treated group with tusca leaves 10\% HE (150 mg/ $\mathrm{kg})$. Arrows mark mucus stained with Alcian Blue.

Scale bars $=25 \mu \mathrm{m}$. I: infusion of $A$. aroma leaves, HE: hydroalcoholic extract of $A$. aroma leaves. Full page width.

\section{Determination of gastric wall mucus}

As shown in Table 2 an oral pretreatment with tusca leaf infusion caused a significant increase (3.35 times) in the amount of adherent acid mucinlike glycoproteins compared with the non- pretreated group. As expected, sucralfate enhanced mucus production (3.59 times) and there were no significant differences between the groups treated with sucralfate or with tusca infusion $(p>0.05)$. On the other hand, ethanolic extract pretreatment was not equally effective, showing a significant increase in adherent mucus (2.02 times) compared with the non-pretreated group but to a lesser degree than infusion or sucralfate $(p<0.05)$.

\section{Neutrophil infiltration. MPO activity}

MPO activity, an index of neutrophil infiltration, was significantly increased in the ethanol-treated group compared with the untreated normal group $(p<0.05)$. This result would indicate a substantial neutrophil influx into the gastric mucosa in response to the ethanol injury. As shown in Table 2, this inflammatory effect was markedly attenuated by pretreatment with $5 \%$ I or $10 \%$ HE evidenced by a significant reduction (65 and 62\%, respectively) in MPO activity as compared to the ulcerated untreated group $(p<0.05)$. Comparatively, the sucralfate pretreated group also showed a strongly reduction in gastric MPO activity (76\%) $(p<0.05)$.

\section{Evaluation of gastric mucosal oxidative stress markers in ethanol-treated rats}

Ethanol is a damaging factor that promotes significant GSH depletion in the mucosa $(p<0.05)$ compared with normal untreated animals. Interestingly, oral pretreatment with tusca leaf infusion was able to maintain GSH levels at values similar to the normal control group and to the sucralfate treated group. In contrast, pretreatment with hydroalcoholic extract of tusca leaves was less effective, showing lower GSH levels than those determined in the groups treated with infusion or sucralfate $(p<0.05)$. Despite this significant difference, it should be noted that both pretreatments contributed to maintain GSH levels in the gastric tissue [Table 2].

Ethanol treated rats exhibited a significant increase $(p<0.05)$ in gastric mucosa MDA levels. We observed that pretreatment with either 5\% I or $10 \%$ HE significantly decreased MDA tissue accumulation promoted by ethanol [Table 2]. In the same way as was observed with GSH levels, tusca infusion pretreatment was significantly more effective $(p<0.05)$ than alcoholic extract in preventing lipid peroxidation. 


\begin{tabular}{|c|c|c|c|c|c|}
\hline Treatments & $\begin{array}{c}\text { Mucus } \\
\text { ( } \mu \mathrm{g} \text { of Alcian } \\
\text { Blue/g stomach) }\end{array}$ & $\begin{array}{c}\text { GSH } \\
\text { ( } \mu \mathrm{g} \mathrm{GSH} / \mathrm{mg} \\
\text { protein) }\end{array}$ & $\begin{array}{c}\text { MDA } \\
\text { (pmol /mg } \\
\text { protein) }\end{array}$ & $\begin{array}{c}\text { CAT } \\
\text { (U/mg protein) }\end{array}$ & $\begin{array}{c}\text { MPO } \\
\text { (U/mg } \\
\text { protein) }\end{array}$ \\
\hline Vehicle & $32.13 \pm 1.61$ & $251.64 \pm 12.58$ & $0.97 \pm 0.05$ & $291.41 \pm 14.57$ & $0.70 \pm 0.03$ \\
\hline Ethanol $100^{\circ}$ & $9.28 \pm 0.46$ & $11.29 \pm 0.56^{\mathrm{a}}$ & $102.51 \pm 5.13^{\mathrm{a}}$ & $568.11 \pm 28.41^{\mathrm{a}}$ & $2.01 \pm 0.10^{\mathrm{a}}$ \\
\hline $\begin{array}{l}\text { Sucralfate } \\
(100 \mathrm{mg} / \mathrm{kg})\end{array}$ & $33.35 \pm 1.67^{\mathrm{a}}$ & $237.36 \pm 11.87^{\mathrm{b}}$ & $0.57 \pm 0.03^{\mathrm{a}, \mathrm{b}}$ & $151.38 \pm 7.57^{\mathrm{a}, \mathrm{b}}$ & $0.48 \pm 0.02^{\mathrm{a}, \mathrm{b}}$ \\
\hline $\begin{array}{c}5 \% \mathrm{I} \\
(150 \mathrm{mg} / \mathrm{kg})\end{array}$ & $31.13 \pm 1.56^{\mathrm{a}}$ & $253.94 \pm 12.70^{\mathrm{b}}$ & $27.92 \pm 1.40^{\mathrm{a}, \mathrm{b}, \mathrm{c}}$ & $225.38 \pm 11.27^{\mathrm{a}, \mathrm{b}, \mathrm{c}}$ & $0.74 \pm 0.04^{\mathrm{b}, \mathrm{c}}$ \\
\hline $\begin{array}{c}10 \% \mathrm{HE} \\
(150 \mathrm{mg} / \mathrm{kg})\end{array}$ & $18.81 \pm 0.94^{\mathrm{a}, \mathrm{b}, \mathrm{c}}$ & $111.94 \pm 5.60^{\mathrm{a}, \mathrm{b}, \mathrm{c}, \mathrm{d}}$ & $32.43 \pm 1.62^{\mathrm{a}, \mathrm{b}, \mathrm{c}, \mathrm{d}}$ & $370.77 \pm 18.54^{\mathrm{a}, \mathrm{b}, \mathrm{c}, \mathrm{d}}$ & $0.78 \pm 0.04^{\mathrm{a}, \mathrm{b}}$ \\
\hline
\end{tabular}

Data are presented as the means \pm SD for $\mathrm{n}=6$ rats per group in an ethanol induced ulcer model. ${ }^{\mathrm{a}} p<0.05 \mathrm{vs}$. normal group, ${ }^{b} p<0.05$ vs. control ulcer group, ${ }^{c} p<0.05$ vs. sucralfate control group, ${ }^{d} p<0.05$ vs. tusca $5 \%$ I treated group. I: infusion, HE: hydroalcoholic extract, GSH: glutathione, MDA: malondialdehyde, CAT: catalase, MPO: myeloperoxidase.

Table 3: Effects of $A$. aroma leaves extracts on gastric secretion parameters.

\begin{tabular}{ccccc}
\hline Treatments & $\begin{array}{c}\text { Gastric juice } \\
\text { volume }(\mathrm{ml})\end{array}$ & $\mathrm{pH}$ & $\begin{array}{c}\text { Free Acid } \\
(\mathrm{mEq} / \mathrm{L} / 100 \mathrm{~g} \text { bw })\end{array}$ & $\begin{array}{c}\text { Pepsin activity }(\mu \mathrm{M} \\
\text { tyrosine } / \mathrm{ml})\end{array}$ \\
\hline Vehicle & $4.5 \pm 0.01$ & 1.0 & $43.2 \pm 2.2$ & $16.32 \pm 0.82$ \\
Omeprazole $(20 \mathrm{mg} / \mathrm{kg})$ & $1.5 \pm 0.01^{\mathrm{a}}$ & 5.0 & $0.0^{\mathrm{a}}$ & $2.85 \pm 0.14^{\mathrm{a}}$ \\
Tusca $5 \% \mathrm{I}(150 \mathrm{mg} / \mathrm{kg})$ & $2.5 \pm 0.01^{\mathrm{a}, \mathrm{b}}$ & 1.0 & $34.3 \pm 1.7^{\mathrm{a}, \mathrm{b}}$ & $12.28 \pm 0.61^{\mathrm{a}, \mathrm{b}}$ \\
Tusca $10 \% \mathrm{HE}(150 \mathrm{mg} / \mathrm{kg})$ & $4.5 \pm 0.01^{\mathrm{b}, \mathrm{c}}$ & 1.0 & $33.3 \pm 1.7^{\mathrm{a}, \mathrm{b}}$ & $11.53 \pm 0.58^{\mathrm{a}, \mathrm{b}}$ \\
\hline
\end{tabular}

Data are presented as the means \pm SD for $n=6$ rats per group in a pylorus ligation model. ${ }^{a} p<0.05$ vs. negative control group, ${ }^{b} p<0.05$ vs. omeprazole (positive control drug) treated group, ${ }^{c} p<0.05$ vs. tusca $5 \%$ I treated group. I: infusion, HE: hydroalcoholic extract, bw: body weight.

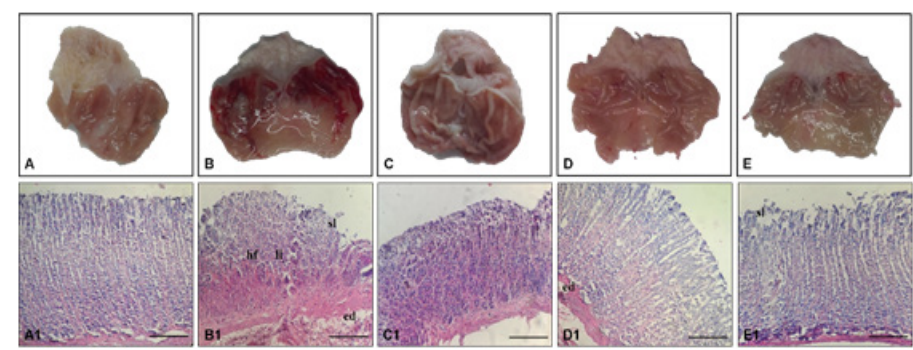

Figure 1: Macroscopic appearance and histological analysis of the rat's stomachs.

It is interesting to note that the animals pretreated with $5 \%$ I or $10 \%$ HE showed significantly lower values $(p<0.05)$ of CAT activity compared to control ulcer animals, whereas sucralfate pretreatment showed still much lower values in the enzyme activity.

\section{Evaluation of the in vivo effects of $5 \%$ infusion and $10 \%$ hydroalcoholic extract of $A$. aroma leaves on rat pylorus ligation model}

We studied the effect of 5\% I and 10\% HE on gastric juice parameters such as volume, $\mathrm{pH}$ and free acid using a rat pylorus ligation model. Although treatment with the infusion caused a significant decrease in the

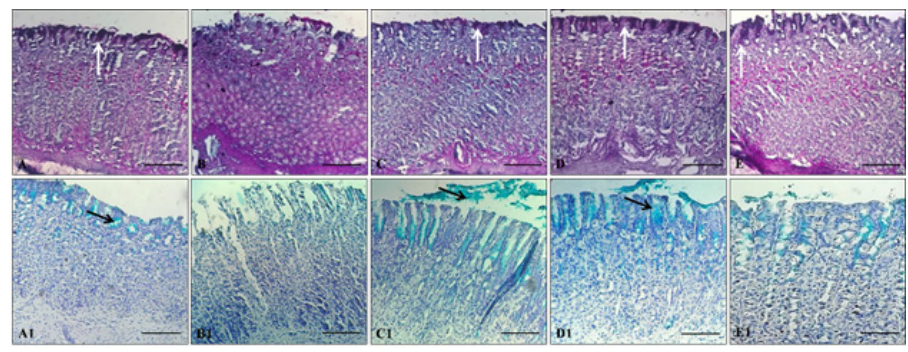

Figure 2: Histochemical analysis of gastric mucosa stained with PAS (Periodic Acid Shiff) and Alcian Blue dye.

volume of gastric juice and free acid content compared with untreated animals, it did not change their $\mathrm{pH}$. Similar results were obtained when treating the animals with $10 \% \mathrm{HE}$, but with no volume reduction [Table 3]. Only the group treated with omeprazole (an effective anti-secretory drug) at a dose of $20 \mathrm{mg} / \mathrm{kg}$ displayed a significant decrease in the volume of gastric juice accompanied by a drastic decrease in free acid and a rise in $\mathrm{pH}$.

The activity of pepsin in the gastric juice of the animals treated with $5 \%$ I or $10 \%$ HE was significantly lower $(p<0.05)$ than in the untreated animals; however, it was not reduced to the levels found in the animals treated with omeprazole, as shown in Table 3. 


\section{DISCUSSION}

Acacia aroma Gill. ex Hook. and Arn. is a medicinal plant with extensive use in folk medicine ${ }^{13}$ and the present work highlights the gastroprotective effects of two extracts from its aerial part using ethanol-induced gastric ulcer models in rats.

The phytochemical analysis of 5\% I and 10\% HE showed a rich content of chemicals species such as flavonoids and tannins. Flavonoids from several plants have a significant gastroprotective activity in experimental models of gastric ulceration, mainly due to their cytoprotective, antisecretory and antioxidant properties. ${ }^{28}$ Tannin-containing herbs have been proposed to treat mild gastric ulcers because of the ability of these compounds to form complexes with proteins of cell membranes and mucus itself and also because of their antioxidant capacity. ${ }^{29}$ Given these evidences, we focused on the antiulcerogenic potential of the tusca leaf extracts using an ulcer induced experimental model in rats.

The starting point of this study was the determination of the protective effectiveness of tusca extracts on the gastric mucosa subjected to a harmful agent. Under our experimental conditions, absolute ethanol has the ability to damage the gastric mucosa to a large extent, as shown by macroscopic and microscopic analyses. Interestingly, 5\% I and 10\% HE prevented mucosa injury when administered orally in rats. The minimum effective dose for both preparations was $150 \mathrm{mg} / \mathrm{kg}$.

Increased mucus secretion by gastric mucosal cells seems to be important in acute protection. ${ }^{30}$ It should be emphasized that our experimental model implies the use of a single effective dose of each vegetal extract as a pretreatment in experimental animals. Under this condition, we demonstrated an effective increase in mucus content in animals pretreated with $5 \%$ I or $10 \% \mathrm{HE}$, similar to the effect of sucralfate. It is likely that enhanced secretion and release of mucus could contribute to an intraluminal dilution of damaging agents, it being a rapid strategy to prevent mucosal injuries, as proposed by Szabo. ${ }^{7}$ We think that the increased mucus content noted in pretreated rats could be attributed to the presence of flavonoids in the extracts, a plant compound with recognized mucus secretagogue activity. ${ }^{28}$

We also studied the effect of 5\% I and 10\% HE on gastric juice parameters using a pylorus ligation model in rats. ${ }^{31}$ The treatments with both tusca extracts had just a little antisecretory effect and cause a small change in the free acid concentration, with a slight decrease in pepsin activity. Taking the above results together, it would be possible to affirm that the tusca extracts strengthened the mucosal barrier with a slightly reduction of gastric acidity. These findings are similar to the effect of most of the available bismuth salts, ${ }^{32}$ which supports the gastroprotective concept of the tusca preparations evaluated in the present work.

The presence of gastric ulcers has been associated with an increase in MPO activity, a marker of neutrophil infiltration. ${ }^{33}$ Under our experimental conditions, ethanol-induced mucosal injury was accompanied by inflammatory cell infiltration and a consequent increase in MPO activity. Interestingly, rats pretreated with tusca extracts showed no gastric inflammation and normal levels of MPO activity. We think that these effects could be important to break the vicious cycle that exists between infiltration of inflammatory cells and the formation of Reactive Oxygen Species (ROS), as was observed in several studies. ${ }^{34}$

Oxidative stress results from an imbalance between the generated ROS and the available antioxidant capacity. The involvement of sequential ROS-mediated induction of lipid peroxidation in the pathogenesis of gastric injury has been widely confirmed, the infiltrating inflammatory cells being a major source of ROS production. ${ }^{34}$ In this regard, an effective protector of gastric mucosa should increase antioxidant defenses and/or eliminate free radicals.
Flavonoids and all polyphenols in general, have a free radical scavengers potential, mainly in organs exposed to high concentrations thereof such as the gastrointestinal tract. ${ }^{35}$ In this work it is possible to suggest that, at least in part, the gastroprotective effect elicited by tusca extracts could be associated with both, the in vitro ability to scavenge free radicals and the flavonoid content.

It is well established that several polyphenol compounds enhance the activities of glutathione reductase and other enzymes, contributing to a stable GSH supply. ${ }^{36}$ We observed a significant preservation of the gastric mucosal GSH levels in animals pretreated with 10\% HE but particularly with $5 \%$ I. Thus, it is possible to suggest that the above treatments increase GSH availability to reduce intrinsic oxidative stress after ethanol administration.

CAT is a key antioxidant enzyme to defend cells against the damaging effects of oxygen free radicals. ${ }^{37}$ The data presented here indicates a lesser CAT activity in the gastric mucosa of animals pretreated with 5\% I or $10 \% \mathrm{HE}$ compared with rats receiving only ethanol. This leads us to suggest that the free radical scavenging capacity of extracts and their positive effects on GSH levels could allow the gastric mucosa to overcome the oxidative effect of alcohol with no need of increased CAT activity. Ethanol-induced oxidative stress evidenced by high levels of MDA in gastric tissue, in a process probably dependent on neutrophil infiltration and activation. ${ }^{38}$ However, the animals pretreated with both extracts of tusca leaves showed lower MDA levels. These findings reflect a protective effect against the oxidative damage caused by ethanol.

The pharmacological potential of a plant extract necessarily requires a toxicological analysis that justifies its safe use thereof. A. aroma is a plant often used in traditional folk medicine. ${ }^{13}$ Although this fact could account for its safety, there is not scientific information about its toxicity. In the present work, we evaluated the acute toxic effect of 5\% I and $10 \% \mathrm{HE}$ in healthy male and female adult rats. The lack of toxic effects at all doses up to the highest one tested suggested that the lethal dose 50 of both extracts would be above $15 \mathrm{~g} / \mathrm{kg}$. Although this result allows us to suggest a high safety margin for the two extracts assayed, additional experiments are in progress to complete their toxicological profile.

\section{CONCLUSION}

This study shows for the first time the gastroprotective efficacy of 5\% I and $10 \% \mathrm{HE}$ as a pretreatment in an animal model of ethanol-induced gastric damage. The observed effect can be attributed to their antioxidant activity and neutrophil infiltration inhibition as well as to an increase in mucus secretion by gastric mucosal cells. Thus, the current study highlights the benefits of tusca extracts as a prophylactic approach to maintain gastric mucosal integrity.

\section{ACKNOWLEDGEMENT}

We wish to thank Ms. Virginia Méndez for her proof-reading.

\section{CONFLICT OF INTEREST}

The authors declare no conflict of interest.

\section{ABBREVIATIONS}

ANOVA: Analysis of variance; BSA: bovine serum albumin; CAT: Catalase; DPPH: 2,2-diphenyl-1- picrylhydrazyl; EDTA: etilendiamino tetraacetic; GAE: Gallic acid equivalent; GSH: Glutathione; HE: Hydroalcoholic extract of tusca leaves; I: Infusion of tusca leaves MDA: Malondialdehyde; MPO: Myeloperoxidase; NOAEL: Non-observed-adverse-effect level; PAS: Periodic acid shiff; PBS: Phosphate buffer saline; ROS: Reactive oxygen species. 


\section{REFERENCES}

1. Najm WI. Peptic ulcer disease. Prim Care. 2011;38(3):383-94. https://doi. org/10.1016/j.pop.2011.05.001

2. Tarnawski AS. Cellular and molecular mechanisms of gastrointestinal ulcer healing. Dig Dis Sci. 2005;50(1):24-33. https://doi.org/10.1007/s10620-005-2803-6

3. Zatorski H. Pathophysiology and Risk Factors in Peptic Ulcer Disease: Introduction to Gastrointestinal Diseases Lodz: Springer International Publishing AG. 2017;2:7-21. https://doi.org/10.1007/978-3-319-59885-7

4. Li NS, Luo XJ, Dai Z, Liu B, Zhang YS, Yang ZC, et al. Beneficial effects of capsiate on ethanol-induced mucosal injury in rats are related to stimulation of calcitonin gene-related Peptide reslease. Planta Med. 2012;78(1):24-30. https:// doi.org/10.1055/s-0031-1280217

5. Lu H, Graham DY. New development in the mechanistic understanding of peptic ulcer diseases. Drug Discov Today Dis Mech. 2006;3(4):431-7. https://doi. org/10.1016/j.ddmec.2006.07.001

6. Yuan Y, Padol IT, Hunt RH. Peptic ulcer disease today. Nat Clin Pract Gastroenterol Hepatol. 2006;3(2):80-9. https://doi.org/10.1038/ncpgasthep0393

7. Szabo S. "Gastric cytoprotection" is still relevant. J Gastroenterol Hepatol. 2014;29(Suppl )4:124-32. https://doi.org/10.1111/jgh.12735

8. Glavin GB, Szabo S. Experimental gastric mucosal injury: Laboratory models reveal mechanisms of pathogenesis and new therapeutic strategies. FASEB J. 1992;6(3):825-31. https://doi.org/10.1096/fasebj.6.3.1740232

9. Adinortey MB, Ansah C, Galyuon I, Nyarko A. In vivo Models Used for Evaluation of Potential Antigastroduodenal Ulcer Agents. Ulcers. 2013;2013:1-12. http://dx.doi.org/10.1155/2013/796405

10. Schmeda-Hirschmann G, Yesilada E. Traditional medicine and gastroprotective crude drugs. J Ethnopharmacol. 2005;100(1-2):61-s6. https://doi.org/10.1016/j. jep.2005.06.002

11. Burkart A. Las leguminosas argentinas silvestres y cultivadas, $2^{\text {nd }}$ ed. Buenos Aires: Acme Agency. 1952.

12. Martínez GJ, Luján MC. Medicinal plants used for traditional veterinary in the Sierras de Córdoba (Argentina): an ethnobotanical comparison with human medicinal uses. J Ethnobiol Ethnomed. 2011;7(1):23. https://doi.org/10.1186/17464269-7-23

13. Coluccio F. Diccionario folklórico de la flora y la fauna de América, Biblioteca de Cultura Popular. Ediciones Del Sol. 2001;30:349. https://books. google.com.ar/books/about/Diccionario_folkl\%C3\%B3rico_de_la_flora_y_ la.html?id=fDaBNwDKqrcC\&redir_esc=y

14. Mattana CM, Satorres SE, Sosa A, Fusco M, Alcaráz LE. s. Braz J Microbiol. 2010;41(3):581-7. http://dx.doi.org/10.1590/S1517-83822010000300007

15. Mattana CM, Cangiano MA, Alcaráz LE, Sosa A, Escobar F, Sabini C, et al. Evaluation of cytotoxicity and genotoxicity of Acacia aroma leaf extracts. Sci World J. 2014;2014:1-6. http://dx.doi.org/10.1155/2014/380850

16. Seigler DS. Phytochemistry of Acacia- sensu lato. Biochem Syst Ecol. 2003;31(8):845-73. http://agris.fao.org/agris-search/search. do? recordID $=$ US201600075804

17. Farmacopea Argentina. $7^{\circ} \mathrm{C}$ edición. Formas Farmacéuticas. ; http://www.anmat.gov.ar/webanmat/fna/pfds/Farmacopea_Argentina_2013_Ed.7.pdf

18. Chang CC, Yang MH, Wen HM, Chern JC. Estimation of total flavonoid content in propolis by complementary colorimetric methods. J Food Drug Anal. 2002;10(3):178-82. https://pdfs.semanticscholar.org/b3de/ c5e57477b0489135bd5b43a27f9b7cee7d31.pdf

19. Ricco RA, Agudelo IJ, Wagner ML. Métodos empleados en el análisis de polifenoles en un laboratorio de baja complejidad. Lilloa. 2015;52(2):161-74. http:// www.lillo.org.ar/revis/lilloa/2015-52-2/07.pdf
20. Blois MS. Antioxidant determinations by the use of a stable free radical. Nature. 1958;181:1199-200. https://doi.org/10.1038/1811199a0

21. Corne SJ, Morrisey SM, Woods RJ. A method for the quantitative estimation of gastric barrier mucus. J Physiol. 1974;242(2):116-7. https://onlinelibrary.wiley. $\mathrm{com} /$ openurl ? spage $=116 \mathrm{P} \&$ genre $=$ article $\& i s s n=0022-3751 \& \mathrm{sid}=\mathrm{n} / \mathrm{m} \% 3 \mathrm{Apub}$ med\&date $=1974 \&$ volume $=242$

22. Lowry $\mathrm{OH}$, Rosebrough NJ, Farr AL, Randall RJ. Protein measurement with the Folin phenol reagent. J Biol Chem. 1951;193(1):265-75. http://www.jbc.org/ content/193/1/265.long

23. Ellman GC. Tissue sulfhydryl groups. Arch Biochem Biophy. 1959;82(1):70-7. https://doi.org/10.1016/0003-9861(59)90090-6

24. Buege JA, Aust SD. Microsomal lipid peroxidation. Methods Enzymol. 1978;52:302-10. https://doi.org/10.1016/S0076-6879(78)52032-6

25. Aebi H. Catalase. Methods Enzyme Anal. 1974;2:673-84. https://doi.org/10.1016/ B978-0-12-091302-2.50032-3

26. Bradley PP, Christensen RD, Rothstein G. Cellular and extracellular myeloperoxidase in pyogenic inflammation. Blood. 1982;60(3):618-22. http://www.bloodjournal.org/content/60/3/618.long?sso-checked=true

27. Anson ML. The estimation of pepsin, trypsin, papain and cathepsin with hemoglobin. J Gen Physiol. 1938;22(1):79-89. https://www.ncbi.nlm.nih.gov/pmc/ articles/PMC2213732/

28. Mota KS, Dias GE, Pinto ME, Luiz-Ferreira A, Souza-Brito AR, Hiruma-Lima CA et al. Flavonoids with gastroprotective activity. Molecules. 2009;14(3):979-1012. https://doi.org/10.3390/molecules14030979

29. De Jesus NZT, de Souza Falcão H, Gomes IF. Tannins, Peptic Ulcers and Related Mechanisms. Int J Mol Sci. 2012;13(3):3203-28. https://doi.org/10.3390/ ijms13033203

30. Szabo S. The mode of action of sucralfate: the $1 \times 1 \times 1$ mechanism of action. Scand J Gastroenterol Suppl. 1991;185:7-12. https://doi. org/10.3109/00365529109093214

31. Brodie DA. The mechanism of gastric hyperacidity produced by pylorus ligation in the rat. Am J Dig Dis. 1966;11(3):231-41. https://doi.org/10.1007/BF02233904

32. Lee SP. The mode of action of colloidal bismuth subcitrate. Scand J Gastroenterol Suppl.1991;185:1-6. https://doi.org/10.3109/00365529109093213

33. Rocha NF, Oliveira GV, Araújo FY, Rios ER, Carvalho AM. (-)- $\alpha$-Bisabolol-induced gastroprotection is associated with reduction in lipid peroxidation, superoxide dismutase activity and neutrophil migration. Eur J Pharm Sci. 2011;44(4):45561. https://doi.org/10.1016/j.ejps.2011.08.020

34. El-Maraghy SA, Rizk SM, Shahin NN. Gastroprotective effect of crocin in ethanol-induced gastric injury in rats. Chem Biol Interact. 2015;229:26-35. https:// doi.org/10.1016/j.cbi.2015.01.015

35. Fraga CG, Galleano M, Verstraeten SV, Oteiza PI. Basic biochemical mechanisms behind the health benefits of polyphenols. Mol Aspects Med. 2012;31(6):43545. https://doi.org/10.1016/j.mam.2010.09.006

36. Ochiai T, Soeda S, Ohno S, Tanaka H, Shoyama Y, Shimeno H. Crocin prevents the death of PC-12 cells through sphingomyelinase-ceramide signaling by increasing glutathione synthesis. Neurochem Int. 2004;44(5):321-30. https://doi. org/10.1016/S0197-0186(03)00174-8

37. Alirezaei M, Dezfoulian O, Neamati S, Rashidipour M, Tanideh N, Kheradmand A. Oleuropein prevents ethanol-induced gastric ulcers via elevation of antioxidant enzyme activities in rats. J Physiol Biochem. 2012;68(4):583-92. https:// doi.org/10.1007/s13105-012-0177-8

38. Kwiecien S, Brzozowski T, Konturek SJ. Effects of reactive oxygen species action on gastric mucosa in various models of mucosal injury. J Physiol Pharmacol. 2002;53(1):39-50. http://www.jpp.krakow.pl/journal/archive/03_02/ pdf/39_03_02_article.pdf

Cite this article: Taboada FF, Habib NC, Genta SB. Gastroprotective Effect of Acacia aroma Gill. ex Hook. and Arn. Leaves Extracts in Gastric Ulcer Models in Rats. Int. J. Pharm. Investigation. 2019;9(4):187-94. 